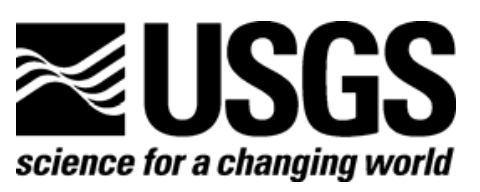

\title{
Rock-Bound Arsenic Influences Ground Water and Sediment Chemistry Throughout New England
}

By Gilpin R. Robinson, Jr., and Joseph D. Ayotte

Open-File Report 2007-1119

U.S. Department of the Interior

U.S. Geological Survey 


\section{U.S. Department of the Interior DIRK KEMPTHORNE, Secretary}

\section{U.S. Geological Survey \\ Mark D. Myers, Director}

U.S. Geological Survey, Reston, Virginia 2007

For product and ordering information:

World Wide Web: http://www.usgs.gov/pubprod

Telephone: 1-888-ASK-USGS

For more information on the USGS - the Federal source for science about the Earth, its natural and living resources, natural hazards, and the environment:

World Wide Web: http://www.usgs.gov

Telephone: 1-888-ASK-USGS

Suggested citation:

Robinson, G.R., Jr. and Ayotte, J. D., 2007, Rock-Bound Arsenic Influences Ground Water and Sediment Chemistry Throughout New England: U. S. Geological Survey Open-File Report 2007-1119, 16 p.

Any use of trade, product, or firm names is for descriptive purposes only and does not imply endorsement by the U.S. Government.

Although this report is in the public domain, permission must be secured from the individual copyright owners to reproduce any copyrighted material contained within this report. 


\section{Contents}

Abstract

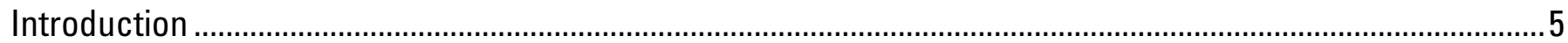

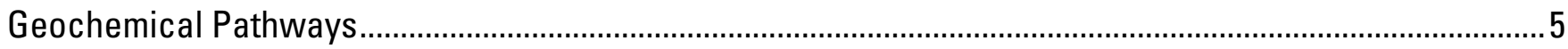

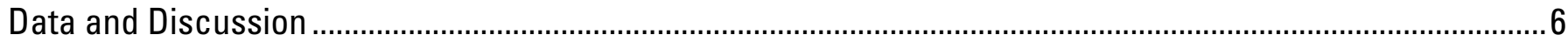

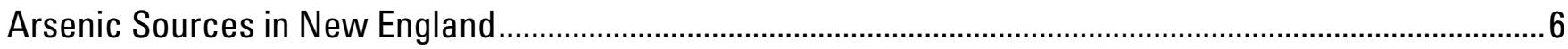

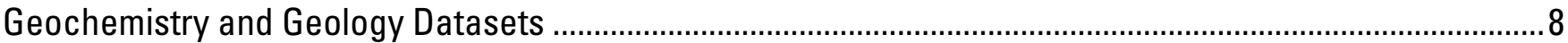

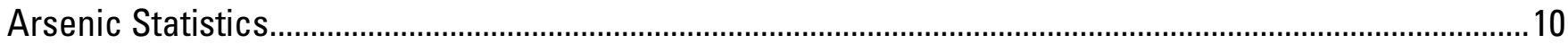

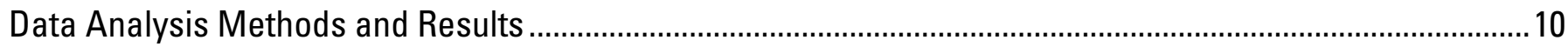

Contingency Table Data Analysis.................................................................................................. 10

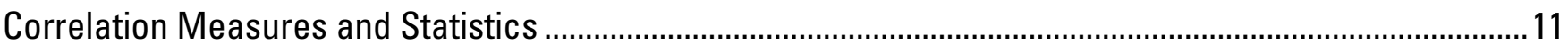

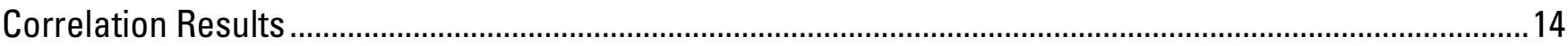

Correlation of wells, split into high and low categories, relative to stream sediment data........................14

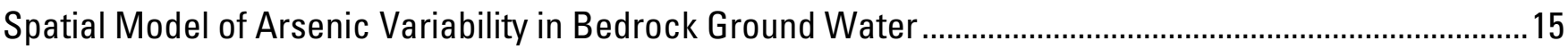

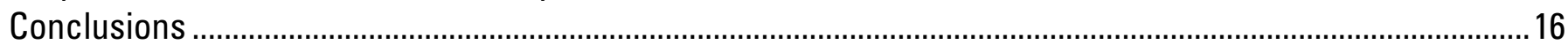

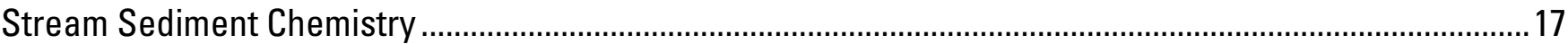

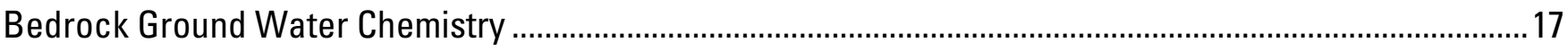

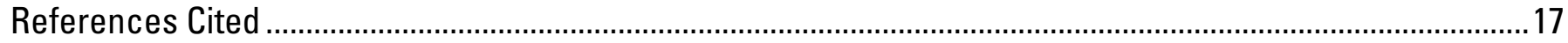

\section{Figures}

Figure 1. Geochemical pathways involve source factors, process factors that act on sources, and transport factors that collectively influence chemical concentrations in sediment, water, and biological receptors

Figure 2. Agricultural lands that used arsenical pesticides and herbicides in New England..........................7

Figure 3. Arsenic geochemistry datasets for rock, stream sediment and bedrock well water samples.........8

Figure 4. Generalized lithology of bedrock geologic units in New England.

Figure 5. Box plots and summary statistics for arsenic concentrations in rock, stream sediment (Sseds), and well water samples.

Figure 6. Box plots and summary statistics for rock arsenic data grouped by lithology.

Figure 7. Plot of log-transformed Odds ratio defined by high-As and low-As classified well variables, on an area basis, versus classes of increasing stream sediment chemistry.

Figure 8. Predicted probability of arsenic concentrations $>5 \mu \mathrm{g} / \mathrm{L}$ in ground water wells in bedrock aquifers (Ayotte and others, 2006).

\section{Tables}

Table 1. Contingency table for an example testing association between well classification based on arsenic chemistry and an area classification based on an independent variable. 
Table 2. Summary of ranked Cochran-Mantel-Haenszel statistics for rock (Rocks), stream sediment (Sseds), and groundwater well (wells) sample populations evaluated relative to grouped geologic bedrock map unit (Geology), agricultural index (AGI), stream sediment arsenic interpolation grid (SSgrid), and groundwater well arsenic interpolation grid (Wells) variables. .............................................................13 


\title{
Rock-Bound Arsenic Influences Ground Water and Sediment Chemistry Throughout New England
}

\author{
By Gilpin R. Robinson, Jr., and Joseph D. Ayotte
}

\section{Abstract}

The information in this report was presented at the Northeastern Region Geological Society of America meeting held March 11-14, 2007, in Durham, New Hampshire.

In the New England crystalline bedrock aquifer, concentrations of arsenic that exceed the drinking water standard of $10 \mu \mathrm{g} / \mathrm{L}$ occur most frequently in ground water from wells sited in specific metamorphic and igneous rock units. Geochemical investigations indicate that these geologic units typically have moderately elevated whole-rock concentrations of arsenic compared to other rocks in the region. The distribution of ground water wells with As $>5 \mu \mathrm{g} / \mathrm{L}$ has a strong spatial correlation with specific bedrock units where average whole-rock concentrations of arsenic exceed $1.1 \mathrm{mg} / \mathrm{kg}$ and where geologic and geochemical factors produce high $\mathrm{pH}$ ground water. Arsenic concentrations in stream sediments collected from small drainages reflect the regional distribution of this natural arsenic source and have a strong correlation with both rock chemistry and the distribution of bedrock units with elevated arsenic chemistry. The distribution of ground water wells with As $>5 \mu \mathrm{g} / \mathrm{L}$ has a strong spatial correlation with the distribution of stream sediments where concentrations of arsenic exceed $6 \mathrm{mg} / \mathrm{kg}$. Stream sediment chemistry also has a weak correlation with the distribution of agricultural lands where arsenical pesticides were used on apple, blueberry, and potato crops. Elevated arsenic concentrations in bedrock wells, however, do not correlate with agricultural areas where arsenical pesticides were used. These results indicate that both stream sediment chemistry and the solubility and mobility of arsenic in ground water in bedrock are influenced by host-rock arsenic concentrations. Stream sediment chemistry and the distribution of geologic units have been found to be useful parameters to predict the areas of greatest concern for elevated arsenic in ground water and to estimate the likely levels of human exposure to elevated arsenic in drinking water in New England. However, the extreme local variability of arsenic concentrations in ground water from these rock sources indicate that arsenic concentrations in ground water are affected by other factors in addition to arsenic concentrations in rock.

\section{Introduction}

\section{Geochemical Pathways}

Geochemical pathways involve source factors, process factors that act on sources, and transport factors that collectively influence concentrations in soils, sediments, and waters (Figure 1).

The solubility and mobility of arsenic in ground water are influenced by a variety of processes that often vary locally in bedrock aquifers. Important processes influencing As hydrogeochemistry include 1) oxidation-reduction of sulfides or organic matter that may contain arsenic, 2) desorption or dissolution of ferromanganese hydroxyoxide fracture and grain coatings that may sorb arsenic, and 3) biological transformations involving arsenic (Welch and others, 2000). 


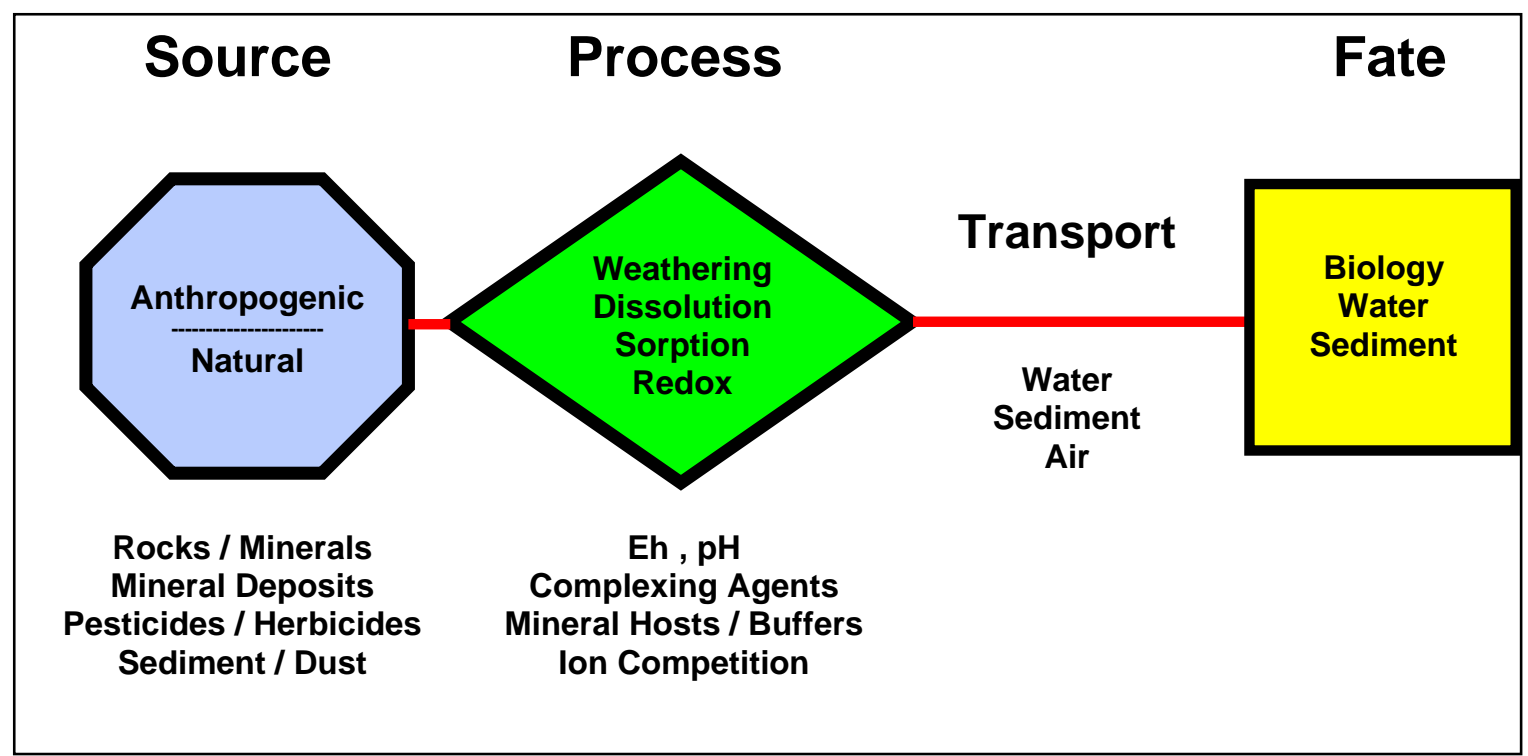

Figure 1. Geochemical pathways involve source factors, process factors that act on sources, and transport factors that collectively influence chemical concentrations in sediment, water, and biological receptors.

This study uses data on ground water chemistry and arsenic sources to evaluate the regional influence of these sources on arsenic concentrations in ground water in crystalline bedrock and in stream sediments. The relative influence of arsenic source factors on arsenic concentrations in ground water is uncertain. We address this uncertainty by measuring the probability that ground water As concentrations $>5 \mu \mathrm{g} / \mathrm{L}$ vary as a function of As source concentrations while controlling for other source and landscape factors. If the correlation measures are positive and significant, we conclude that source type concentrations have influence; if not, process and transport factors likely dominate source factors. Comparison of the correlation measures indicate which sources have the strongest influence on water and sediment chemistry and whether the source variable effects are independent of each other.

\section{Data and Discussion}

\section{Arsenic Sources in New England}

Sources of arsenic that might influence water chemistry in New England aquifers include 1) rocks and mineral deposits, 2) soils and sediments derived from weathering of rocks and 3) anthropogenic sources related to past arsenical pesticide use, industrial contamination, and/or atmospheric deposition of high-As ash from coal combustion.

Robinson and Ayotte (2006) concluded that the most significant anthropogenic source of arsenic in the region is from cumulative applications of arsenical pesticides and herbicides that were used in New England from about 1900 to 1970.

Widespread use of arsenical agricultural compounds occurred during the 1920s to 1950s on agricultural lands containing apple, blueberry, and potato crops. Lead arsenate was the most extensively used arsenical pesticide (Peryea, 1998), particularly in apple orchards. Other metal-bearing pesticides and herbicides, such as copper acetoarsenite (Paris Green), calcium arsenate and sodium arsenate, were used to a lesser degree. 
The application of arsenical pesticides in New England predates systematic record-keeping and the exact locations and amounts of pesticide applications are unknown. However, it is estimated, based on cultivation practices and history, that cumulative application rates of arsenic could have been $200 \mathrm{lbs}$ of elemental arsenic per acre of cultivation (as reported by D'Angelo et al, 1996), equivalent to $22 \mathrm{~g} / \mathrm{m}^{2}$ As. On an area basis, the cumulate application rates for arsenic pesticides applied to apple, blueberry, and potato crops are estimated to be comparable (D'Angelo et al., 1996).

Cultivation data for these crops during this time period (U.S. Department of Agriculture, 19351997) indicate where arsenical pesticides and herbicides were used most extensively in the region.

The cultivation data for crops receiving arsenical pesticide applications from the 1930s to 1970s has been generalized at census tract level to develop an Agricultural Index (AGI; Figure 2) related to arsenical pesticide use. The AGI is used as a proxy for the intensity of arsenical pesticide application in the region.

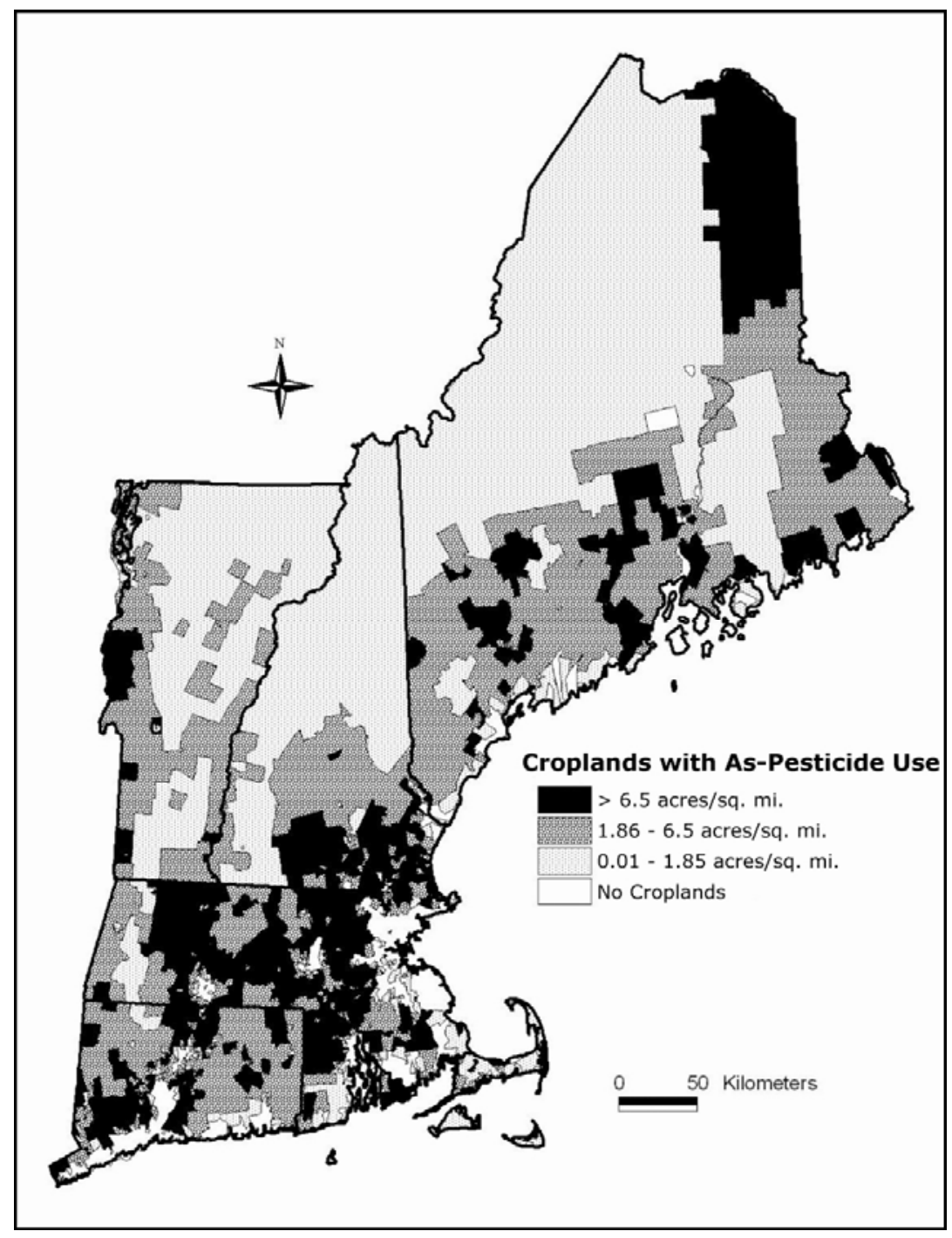

Figure 2. Agricultural lands that used arsenical pesticides and herbicides in New England. The agricultural index value (AGI) portrays the average cultivation rate of apples, blueberries, and potatoes, in units of acres of cultivation per square mile of census tract area, based on agricultural census data from 1935 to 1977 (US Department of Agriculture). 


\section{Geochemistry and Geology Datasets}

Rock chemistry data were restricted to representative rock samples taken from outcrop settings where the rock type is identified. The distribution of rock samples cluster along southwest-northeasttrending transects from 1) southern Connecticut to northern Vermont near the Vermont-New Hampshire border and 2) eastern Connecticut to coastal Maine. Other rock samples are scattered across Connecticut and Maine (Figure 3A).

We analyzed 1,597 stream sediment samples collected from 1977 to 1980 by the National Uranium Resource Evaluation (NURE) Program for As (Figure 3B). The NURE program did not sample drainages in Maine north of $45^{\circ}$ latitude.

Arsenic data for 1,572 bedrock ground-water wells in New England were obtained from state records on public-water supply wells collected for compliance with the Safe Drinking Water Act during the years 1992 to 1999 (Figure 3C). The laboratory reporting level (detection limit) for As in the ground water samples used in this study was variable but no higher than $5 \mu \mathrm{g} / \mathrm{L}$.

The chemical data for stream sediments, rocks, and ground waters have been interpolated into 1 $\mathrm{km}^{2}$ cells so that spatial comparisons could be made.

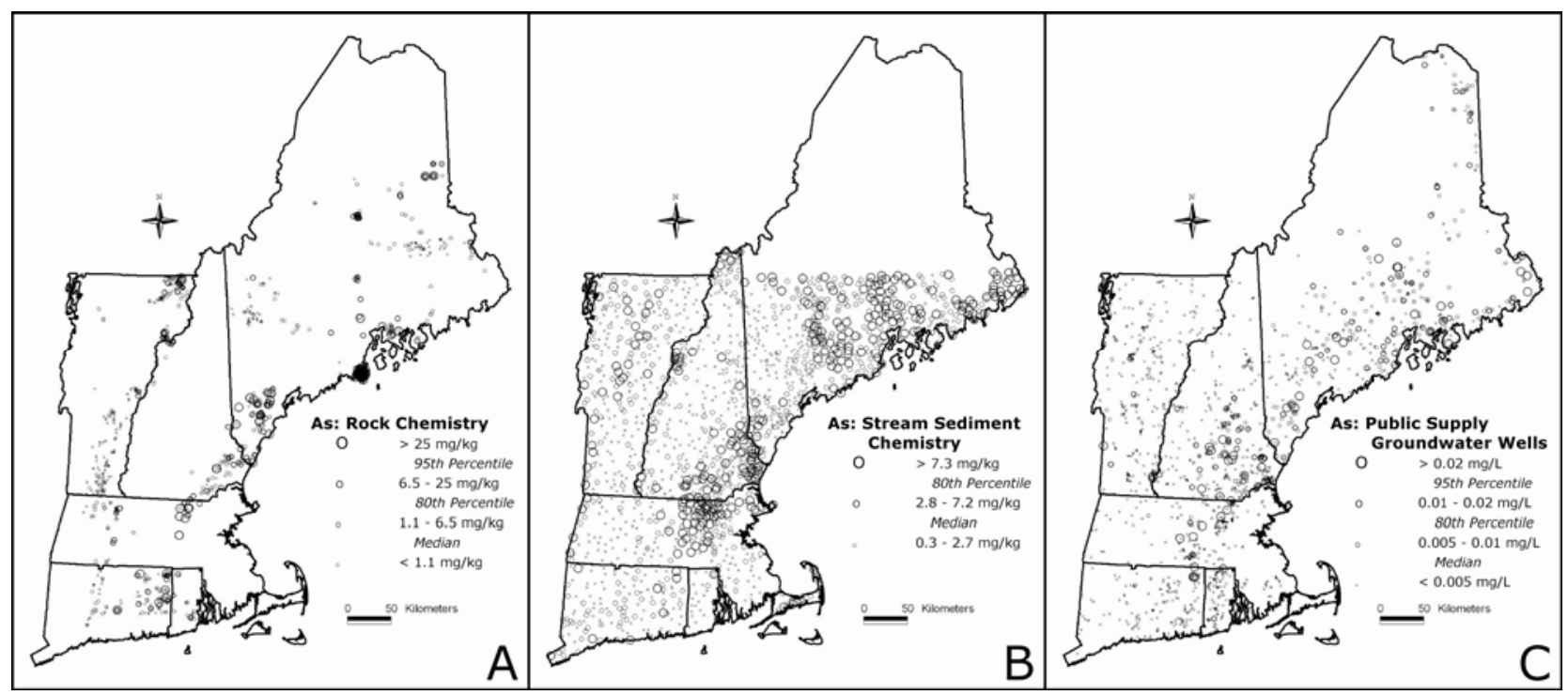

Figure 3. Arsenic geochemistry datasets for rock, stream sediment and bedrock well water samples. The symbol legend for the arsenic concentration data for each sample media is based on percentiles for the ranked arsenic concentrations. A: Rock chemistry sample locations in New England, showing arsenic concentration ranges. Symbol transitions occur at $0.5(1.1 \mathrm{mg} / \mathrm{Kg}), 0.8(6.5 \mathrm{mg} / \mathrm{Kg})$, and $0.95(25$ $\mathrm{mg} / \mathrm{Kg}$ ) percentile values. B: Stream sediment chemistry sample locations in New England, showing arsenic concentration ranges. Symbol transitions occur at $0.5(2.8 \mathrm{mg} / \mathrm{Kg})$ and $0.8(7.3 \mathrm{mg} / \mathrm{Kg})$ percentile values. C: Water chemistry sample locations from public-supply bedrock wells in New England. Symbol transitions occur at $0.5(0.005 \mathrm{mg} / \mathrm{L}), 0.8(0.01 \mathrm{mg} / \mathrm{L})$, and $0.95(0.02 \mathrm{mg} / \mathrm{L})$ percentile values. 
Geologic data on dominant lithology and map unit characteristics were compiled from statewide maps of bedrock geology for the New England states. Over 1,200 individual map units are named and portrayed in these state bedrock geology maps. For analysis of differences in arsenic distributions, the bedrock map units were grouped into lithology and tectonostratigraphic setting categories using map unit descriptions and other geologic information provided with the geologic maps. Generalized lithology groups are in Figure 4.

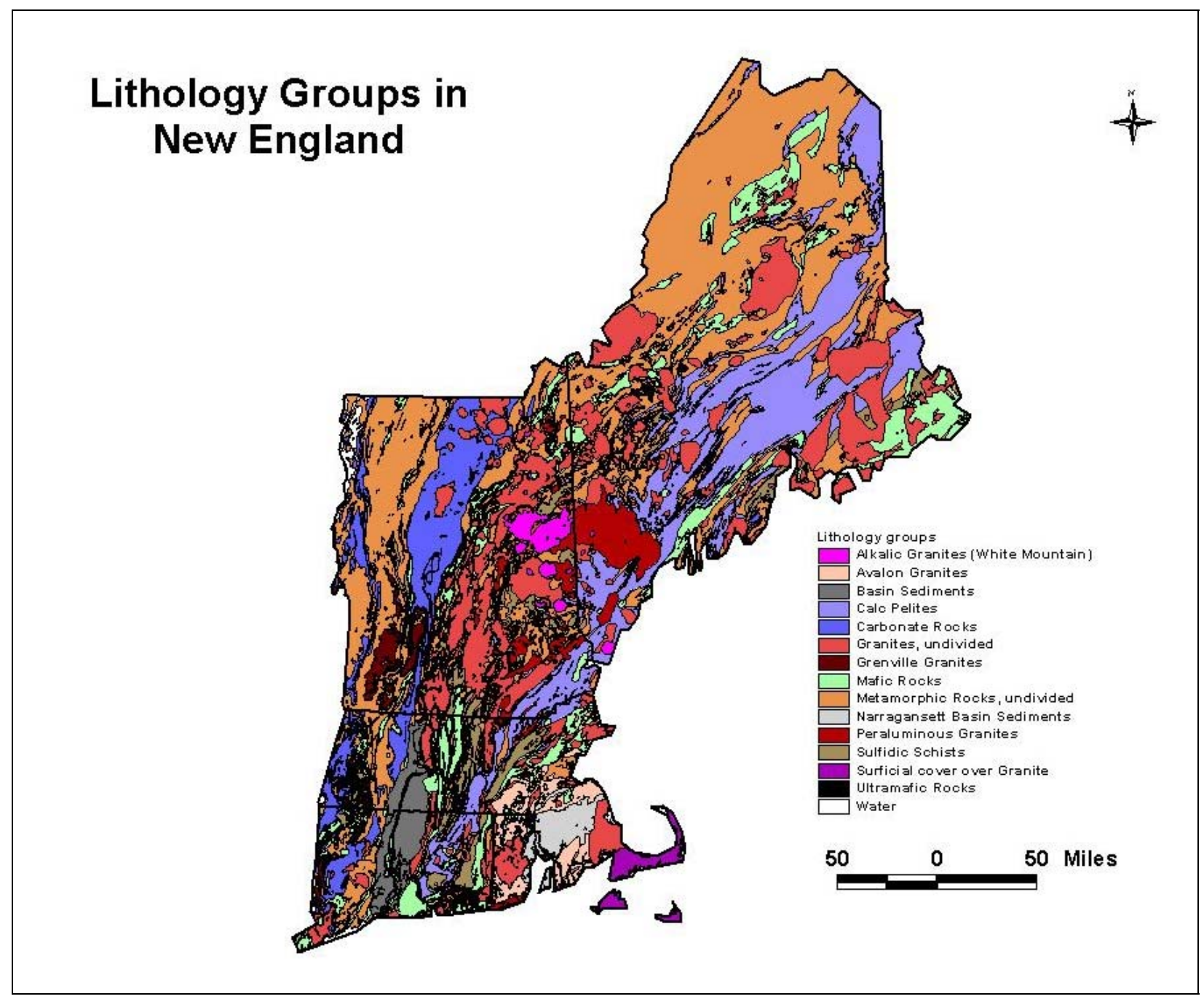

Figure 4. Generalized lithology of bedrock geologic units in New England. The rock types have been grouped into seven general categories based on map unit descriptions and depositional setting information summarized in Robinson and Kapo (2003). 


\section{Arsenic Statistics}

Concentrations of arsenic in rocks, stream sediments, and ground-water wells in bedrock vary by more than two orders of magnitude (Figure 5). The arsenic concentrations show a positively skewed distribution (note the log-transformed Y axis in Figure 5) with median values of $1.1 \mathrm{ppm}(\mathrm{mg} / \mathrm{Kg}), 2.8$ $\mathrm{ppm},<5 \mu \mathrm{g} / \mathrm{L}$ (ppb) for rocks, stream sediments, and ground water, respectively (Table 1).

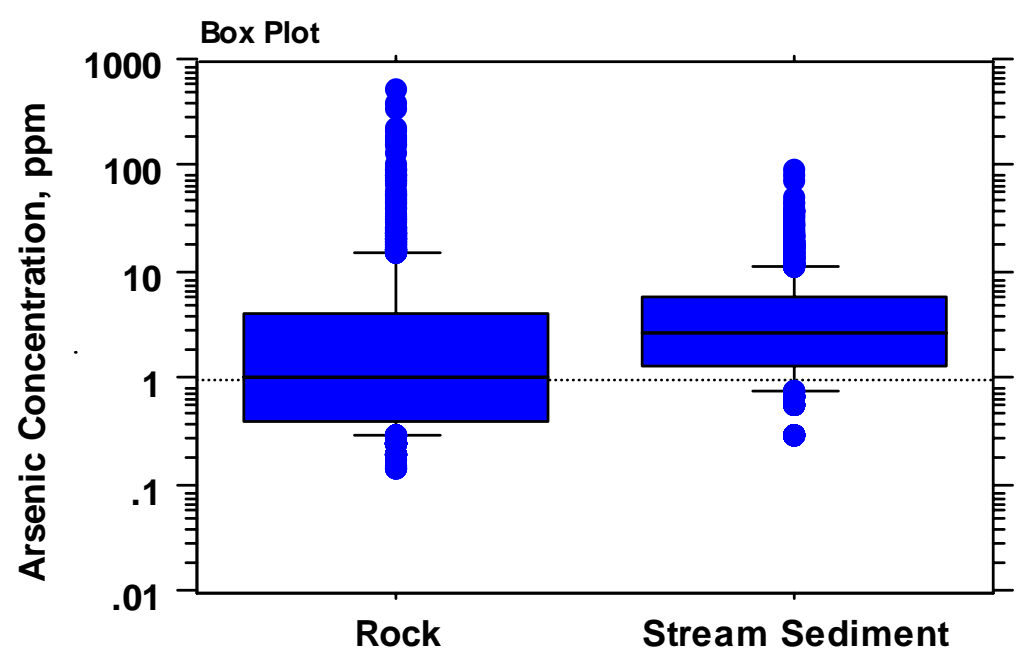

\begin{tabular}{|c|r|r|r|}
\hline $\begin{array}{c}\text { Arsenic } \\
\text { Statistics }\end{array}$ & $\begin{array}{r}\text { Rocks } \\
(\mathrm{ppm})\end{array}$ & $\begin{array}{r}\text { Sseds } \\
(\mathrm{ppm})\end{array}$ & $\begin{array}{r}\text { Wells } \\
(\mu \mathrm{g} / \mathrm{L})\end{array}$ \\
\hline $\mathrm{N}$ & 1279 & 1597 & 1572 \\
\hline Mean & 7.7 & 5.0 & --- \\
\hline Median & 1.1 & 2.8 & $<5.0$ \\
\hline $80 \%$ & 6.7 & 7.2 & 5.0 \\
\hline $90 \%$ & 16.0 & 11.7 & 9.0 \\
\hline
\end{tabular}

Figure 5. Box plots and summary statistics for arsenic concentrations in rock, stream sediment (Sseds), and well water samples. $\mathrm{N}$ is the number of samples for each sample type.

The distribution of arsenic concentrations in rocks, sorted by lithology, shows higher median and mean arsenic concentrations in felsic volcanics relative to granitic rocks and in calcareous metasedimentary and sulfide-rich metamorphic rocks relative to the other lithologic groups in the study area (Figure 6).

\section{Data Analysis Methods and Results}

\section{Contingency Table Data Analysis}

Contingency tables are used to record and analyze the relationship between two or more variables. The table elements, $\mathrm{T}_{\mathrm{ij}}$, are the counts of wells in each table category. (Table 1). 


\begin{tabular}{|c|c||c|c|c|c|c|}
\hline Lithology & $\begin{array}{c}\text { Felsic } \\
\text { Volcanics }\end{array}$ & Granite & Mafic Rocks & $\begin{array}{c}\text { Meta- } \\
\text { calcareous }\end{array}$ & Meta-sulfidic & $\begin{array}{c}\text { Meta- } \\
\text { undivided }\end{array}$ \\
\hline Mean & 9.0 & 2.4 & 1.8 & 24.9 & 21.7 & 16.0 \\
\hline \hline Median & 6.0 & 0.6 & 0.9 & 5.9 & 5.0 & 0.5 \\
\hline
\end{tabular}

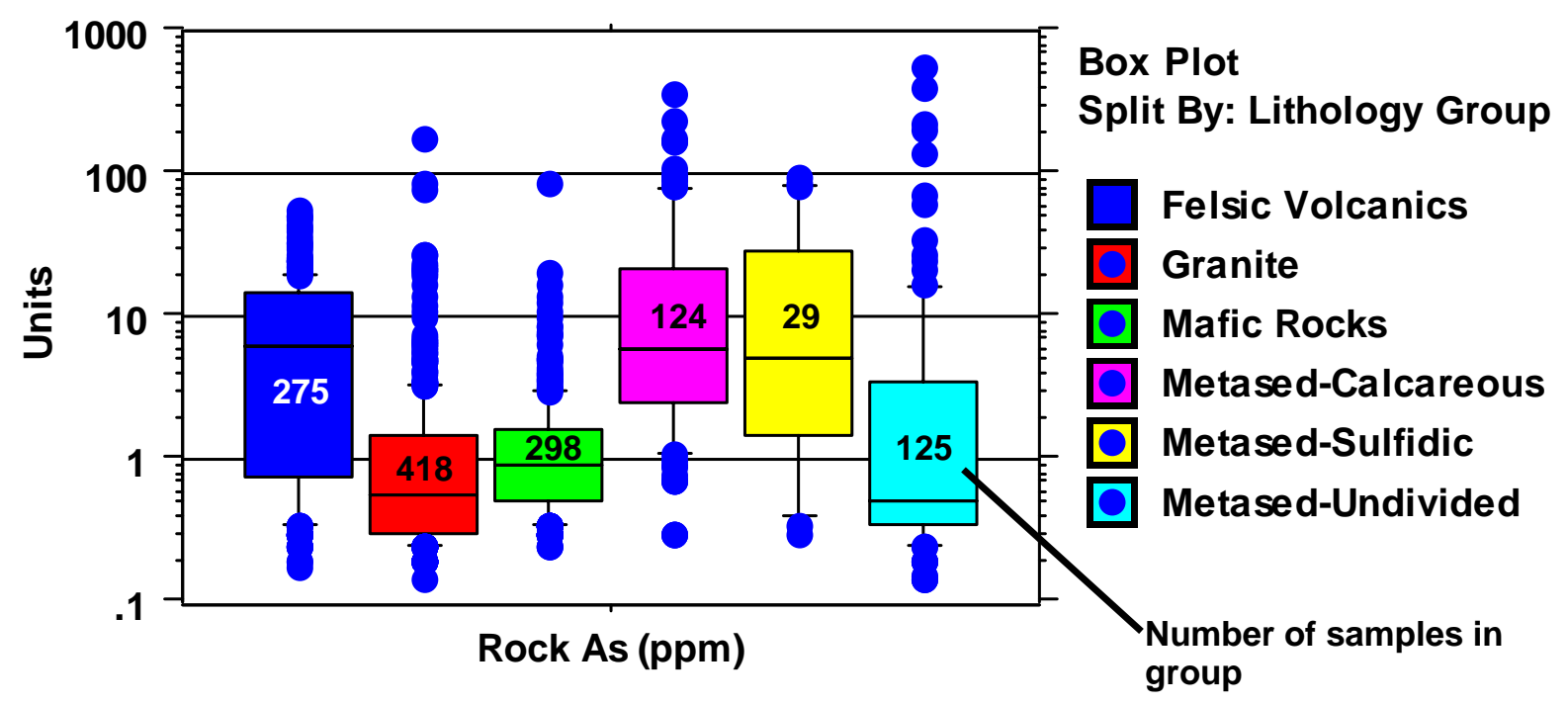

Figure 6. Box plots and summary statistics for rock arsenic data grouped by lithology. Concentration units are in ppm.

The odds ratio measures the discrimination of the relationship. It is the correct classification product divided by the incorrect classification product.

Balanced accuracy measures the performance efficiency of a classification model based on the independent variable classes. It is an average of the correct classification fractions by classification categories. A balanced accuracy of 0.5 is no better than the accuracy expected by random selection.

\section{Correlation Measures and Statistics}

A stratified cross-tabulation contingency-table analysis approach is used to measure strength of the spatial associations between arsenic in rocks, sediments, and ground waters while controlling for the influence and covariance of geologic and agricultural As-pesticide variables. 
Table 1. Contingency table for an example testing association between well classification based on arsenic chemistry and an area classification based on an independent variable.[The table elements, Tij are the counts of wells in each table category.]

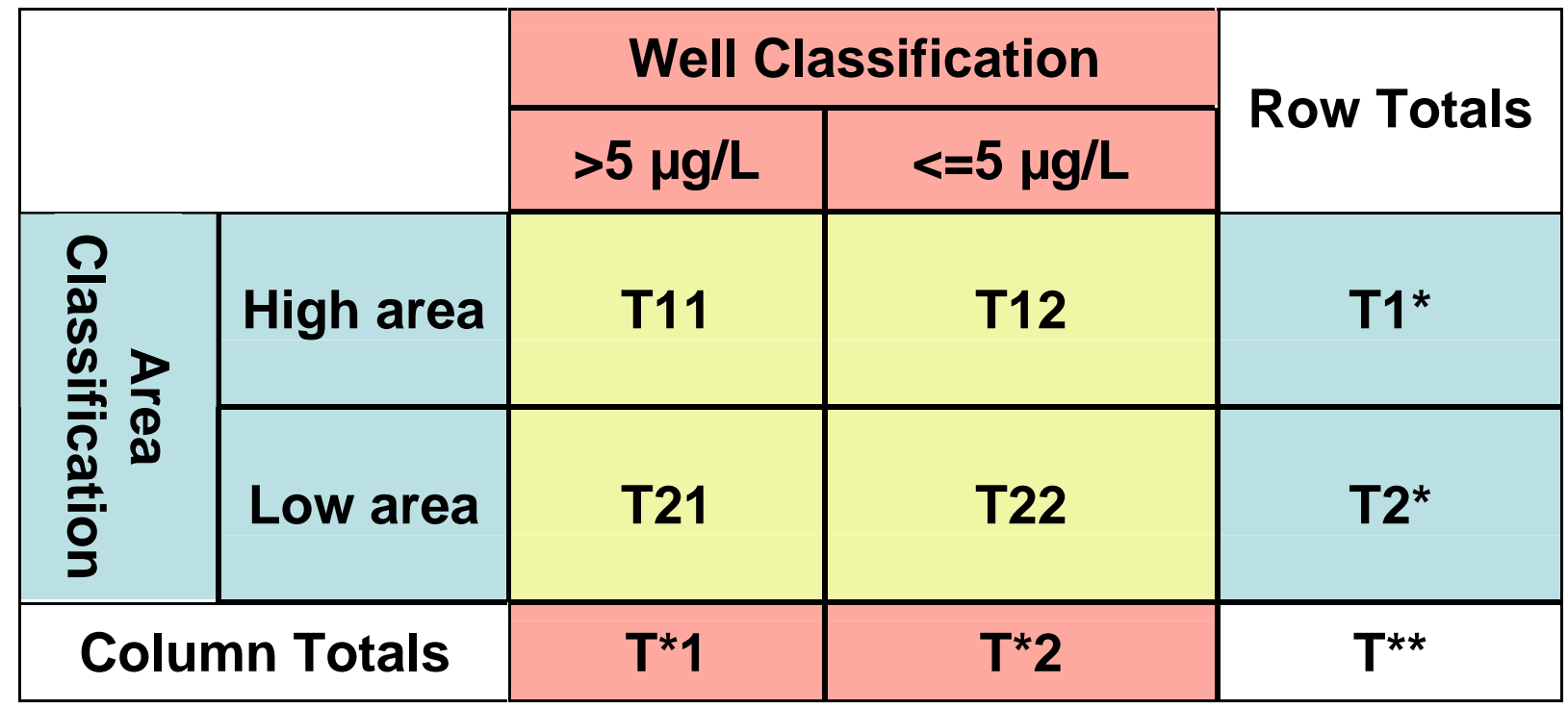

The magnitude of the Mantel-Haenszel Case-control odds ratio, $\mathrm{OR}_{\mathrm{MH}}$, is a measure of the strength of association between the dependent $\mathrm{Y}$ and independent $\mathrm{X}$ variables, as adjusted for the influence of the control variables. An odds ratio of 1 indicates no effect, while a ratio greater than 1 indicates that the independent variable category increases the odds of occurrence of high concentrations in the sample media. Odds ratios not significantly different from 1 at $95 \%$ confidence are shown in red.

The data in Table 2 are grouped by dependent variable (Y var) and are listed in order of decreasing association strength (decreasing $\mathrm{OR}_{\mathrm{MH}}$ ) for each dependent variable group.

The Breslow-Day statistic, $\mathrm{p}(\mathrm{BD})$, measures the probability that the odds ratio of the groups defined by the control variables are not homogeneous. A $p(B D)$ probability $<0.05$ (95\% confidence) means that it is possible to summarize the conditional association between the dependent and explanatory variable by a single odds ratio. Situations where the odds ratio categories differ at $95 \%$ confidence are shown in red. This situation occurs when the explanatory and control variables are influenced by each other but have differing associations with the dependent variable.

The Kappa coefficient $(\mathrm{K})$ measures the correlation agreement between variables and corrects for the amount of correlation expected by random distribution. $\mathrm{K}$ varies from -1 for perfect negative correlation to 0 for random correlation to +1 for perfect correlation. Kappa measures not significantly different from random correlation at $95 \%$ confidence are shown in red.

The non-parametric Spearman's Rho coefficient measures the degree of monotonic correlation between continuous ordered variables. Rho coefficients have been calculated for the continuous dependent and independent data variables when the statistics indicate significant group differences, i.e. when the $\mathrm{OR}_{\mathrm{MH}}$ odds ratios differ from a value of 1.0 at $95 \%$ confidence. 
Table 2. Summary of ranked Cochran-Mantel-Haenszel statistics for rock (Rocks), stream sediment (Sseds), and groundwater well (wells) sample populations evaluated relative to grouped geologic bedrock map unit (Geology), agricultural index (AGI), stream sediment arsenic interpolation grid (SSgrid), and groundwater well arsenic interpolation grid (Wells) variables.

[The threshold values used to group the samples and independent variables into binary categories are identified. The MantelHaenszel Case-control odds ratio, $\mathrm{OR}_{\mathrm{MH}}$, measures the strength of the relationship between the two variables, when adjusted for the control variable. An odds ratio of 1 indicates no effect while a ratio greater than 1 indicates that the independent variable category increases the odds of occurrence of high concentrations in the sample media. Odds ratios not significantly different from 1 at $95 \%$ confidence are shown in red. The data are grouped by dependent variable and listed in order of decreasing $\mathrm{OR}_{\mathrm{MH}}$. The Breslow-Day statistic, $\mathrm{p}(\mathrm{BD})$, measures the probability that the odds ratio of the groups defined by the control variables are homogeneous. Acceptance of the null hypothesis means that it is possible to summarize the conditional association between the dependent and explanatory variable by a single odds ratio. Situations where the odds ratio categories differ at $95 \%$ confidence are shown in red. Kappa (K) measures correlation corrected for randomness. Kappa measures not significantly different from random correlation at $95 \%$ confidence are shown in red. Spearman's Rho correlation coefficients have been calculated for the continuous dependent and independent data variables when the CMH statistic indicates significant group differences. All tests use a 95-percent confidence level.]

\begin{tabular}{|l|l|l|l|r|r|r|c|}
\hline Y var & Threshold & \multicolumn{1}{|c|}{ X var } & Control & OR $_{\mathrm{MH}}$ & $\mathrm{p}(\mathrm{BD})$ & $\mathrm{K}$ & Rho \\
\hline Wells & $5 \mu \mathrm{g} / \mathrm{L}$ & Geology & AGI & 8.755 & 0.5369 & 0.403 & \\
\hline Wells & $5 \mu \mathrm{g} / \mathrm{L}$ & Rocks & AGI & 7.453 & 0.1783 & 0.325 & 0.454 \\
\hline Wells & $5 \mu \mathrm{g} / \mathrm{L}$ & SSgrid & AGI & 3.899 & 0.1577 & 0.237 & 0.283 \\
\hline Wells & $5 \mu \mathrm{g} / \mathrm{L}$ & Rocks & Geo+AGI & 3.050 & 0.0012 & 0.135 & \\
\hline Wells & $5 \mu \mathrm{g} / \mathrm{L}$ & SSgrid & Geo+AGI & 1.918 & 0.0003 & 0.078 & \\
\hline Wells & $5 \mu \mathrm{g} / \mathrm{L}$ & AGI & Geology & 0.819 & 0.5387 & -0.021 & \\
\hline Sseds & $6.0 \mathrm{ppm}$ & Rocks & AGI & 4.253 & 0.9404 & 0.233 & 0.438 \\
\hline Sseds & $6.0 \mathrm{ppm}$ & Geology & AGI & 3.294 & 0.1930 & 0.248 & \\
\hline Sseds & $6.0 \mathrm{ppm}$ & AGI & Geology & 1.630 & 0.1932 & 0.087 & 0.192 \\
\hline Sseds & $6.0 \mathrm{ppm}$ & Rocks & Geo+AGI & 1.518 & 0.0002 & 0.053 & \\
\hline Rocks & $1.1 \mathrm{ppm}$ & SSgrid & AGI & 7.022 & 0.6451 & 0.204 & 0.438 \\
\hline AGI & $6.5 \mathrm{acres} / \mathrm{mi}^{2}$ & Geology & & 1.930 & & & \\
\hline
\end{tabular}

\section{Correlation Results}

Bedrock well arsenic distributions, adjusted for the Agr-index variable (AGI), correlate strongly with the following explanatory variables (in decreasing strength of correlation as indicated by the $\mathrm{MH}$ Odds Ratio): 1) geology , 2) rock chemistry, and 3) stream sediment As (SSgrid) variables (Table 2). The nonsignificant $\mathrm{p}(\mathrm{BD})$ test scores for the geology, rock, and SSgrid variables relative the AGI variable indicate that they are not independent in influence. The strong spatial correlation of the AGI variable with the geology variable $\left(\mathrm{OR}_{\mathrm{MH}}=1.93\right)$ is a likely cause of this effect. The well-rock and wellSSgrid correlations are both positive and significant when the data are adjusted for the influence of both the geology and AGI variables. These correlations have moderate Spearman's Rho measures $(0.454$ and 
0.283 , respectively). These data collectively indicate that elevated groundwater arsenic concentrations correlate most strongly with areas of elevated arsenic concentrations in rocks, the geologic units that host these rocks, and with stream sediments dominated by rock-derived arsenic sources. The correlation of well arsenic distributions with the AGI variable, when adjusted for the geology variable, was not significant. The significance of the $\mathrm{p}(\mathrm{BD})$ test score for the wells-AGI correlation indicate that the nonsignificant $\mathrm{OR}_{\mathrm{MH}}$ statistic is likely the result of no association rather than an inconsistent pattern of association that does not have enough strength or consistency to dominate any other pattern in the controlled strata groups. The stream sediment arsenic distributions, adjusted for the AGI or Geology variables, indicate significant correlation with the following explanatory variables, in decreasing strength of correlation as indicated by the MH Odds Ratio: 1) geology, and 2) AGI. The high values of the $\mathrm{p}(\mathrm{BD})$ test scores indicate that the odds ratios estimated for the stream sediment-wellgrid and stream sediment-geology associations are independent of the controlled AGI variable, and the stream sedimentAGI association is independent of the controlled geology variable. Although the stream sediment arsenic chemistry correlations with the geology and Agr-index variables are both positive and significant, the strength of the stream sediment correlation with the AGI variable is significantly weaker than the correlations with the geology variable.

\section{Correlation of wells, split into high and low categories, relative to stream sediment data}

For ordered variable relationships, the variation in Odds ratio as a function of the classification groups of the independent variable defines the properties of the relationship between dependent and independent variables (Figure 7). The "log of the Odds Ratio" (shown in the Y axis) is the variable fit during logistic regression. This plot shows the high-As and low-As classified well variables, on an area basis, versus classes of increasing stream sediment chemistry. The difference between the high and lowAs well trends is the Odds ratio of the high wells to low wells. For relationships, such as the above, where the log-transformed Odds ratio is linear with increasing independent variable value, the relationship between variables is well described by a continuous variable. The high-As wells increase in odds of occurrence with increasing stream sediment arsenic concentration.

In contrast, the distribution of low-As wells appears to be independent of stream sediment arsenic concentration. The most accurate binary classification based on the independent variable occurs where the two Odds Ratio trends cross at approximately 6 ppm As in stream sediments. Binary classification of the independent variables is needed for the multiple comparison tests between dependent and independent variables that follows. The multiple comparison tests between dependent and independent variables used similar variable classifications for each comparison. 


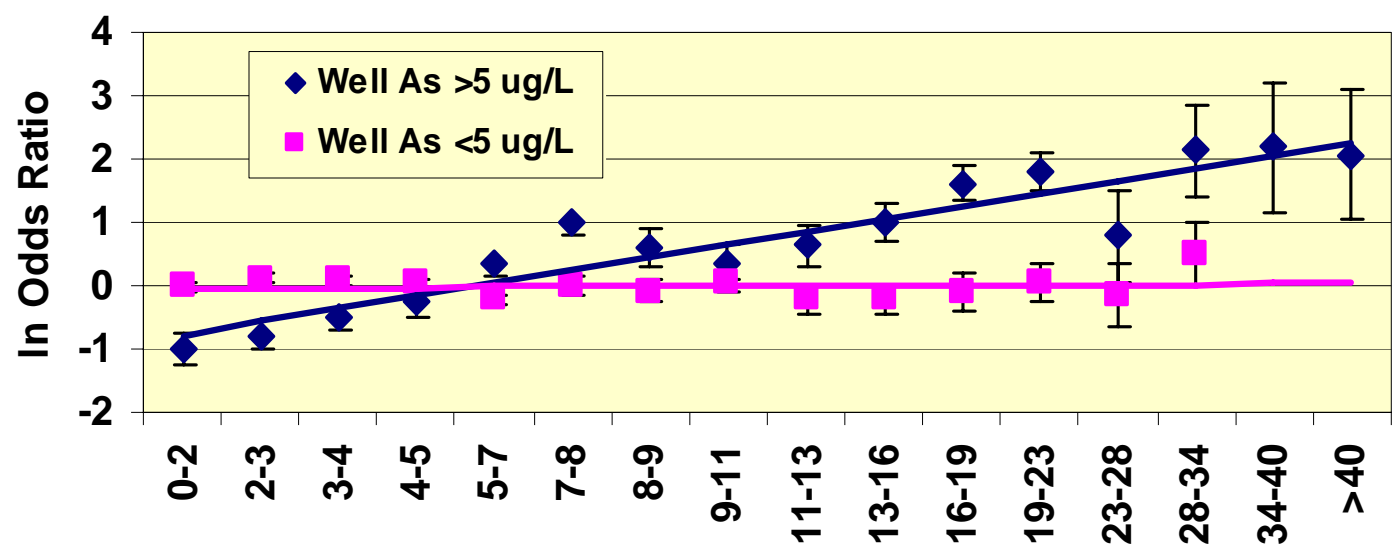

Stream Sediment As range (ppm)

Figure 7. Plot of log-transformed odds ratio defined by high-As and low-As classified well variables, on an area basis, versus classes of stream sediment chemistry defined by arsenic concentration range. The stream sediment arsenic data are discretized into bins with nearly equal log-transformed intervals. One sigma uncertainty intervals for the odds ratio values are shown by tic marks. The solid color lines are linear regression fits to the point data of similar color. The difference between the high and low-As well trends is the odds ratio of the high wells to low wells. The log-transformed odds ratio is the variable fit during logistic regression.

\section{Spatial Model of Arsenic Variability in Bedrock Ground Water}

A statistical model (Ayotte and others, 2006) has been developed to predict the probability of arsenic concentrations exceeding $5 \mu \mathrm{g} / \mathrm{L}$ in bedrock drinking-water wells by geographic area in New England (Figure 8).

Multivariate logistic regression was used to estimate the probability of occurrence of elevated arsenic concentrations in ground water, based on the evaluation of more than 30 geologic, hydrologic, and landscape variables.

Stream sediment chemistry and the distribution of geologic units have been found to be important parameters to predict the areas of greatest concern for elevated arsenic in ground water and to estimate the likely levels of human exposure to elevated arsenic in drinking water in New England (Ayotte and others, 2006). 


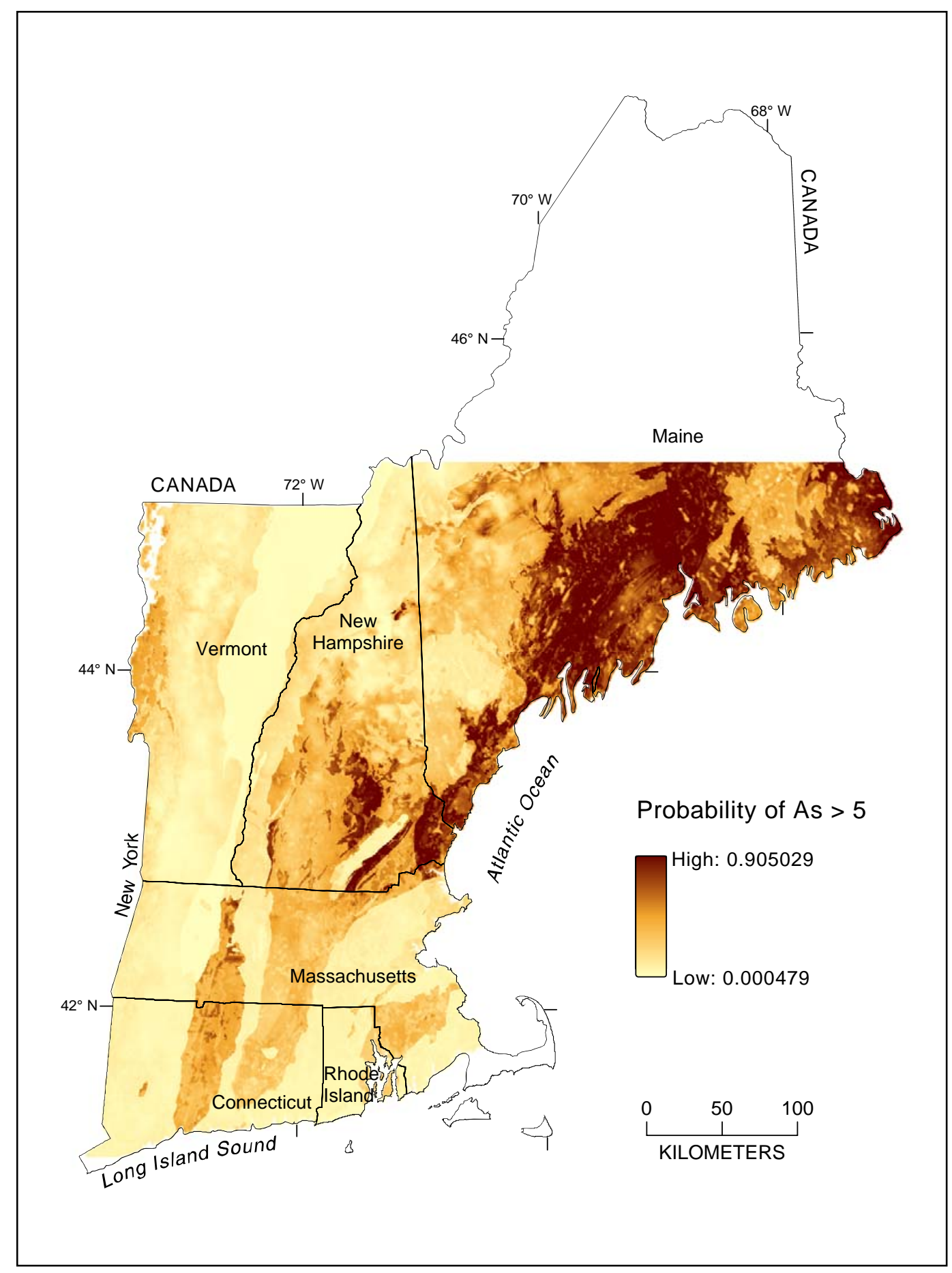

Figure 8. Predicted probability of arsenic concentrations $>5 \mu \mathrm{g} / \mathrm{L}$ in ground water wells in bedrock aquifers (Ayotte and others, 2006). Truncation at 45 degrees north latitude reflects absence of stream sediment data. 


\section{Conclusions}

\section{Stream Sediment Chemistry}

Elevated concentrations of arsenic in stream sediments correlate with elevated rock arsenic concentrations, the geologic units that have elevated rock arsenic concentrations, and areas where arsenical pesticide were used. Calcpelite, felsic volcanic, and sulfidic schist rock types have the highest baseline arsenic concentrations for rocks in the region. Stream sediments integrate arsenic from both rock and arsenical pesticide sources, although the relative influence of rock sources is stronger than arsenical pesticide sources. Mean stream sediment arsenic concentrations grouped by geology and lithology units are typically higher than the corresponding mean rock arsenic concentrations. Weathering appears to concentrate arsenic in soil, and derived sediments, relative to source rock materials.

\section{Bedrock Ground Water Chemistry}

The probability of ground water wells having arsenic concentrations greater than $5 \mu \mathrm{g} / \mathrm{L}$ varies by geology features. The highest ground water probability values correlate with lithology groups and geologic map units mostly occurring in the Coastal Maine and the Central Maine - New Hampshire lithotectonic belts. The well statistics correlate with variation in rock chemistry when the rocks are classified at a threshold of $1.1 \mathrm{ppm}$ As. The well statistics correlate with variation in stream sediment chemistry when the sediments are classified at a threshold of $6.0 \mathrm{ppm}$. The well statistics do not correlate with variation in the intensity of past use of arsenical pesticides. These results indicate that the solubility and mobility of arsenic in ground water in bedrock are influenced by host-rock arsenic concentrations. However, the extreme local variability of arsenic concentrations in ground water from these rock sources indicate that arsenic concentrations in ground water are affected by other factors in addition to arsenic concentrations in rock.

\section{References Cited}

Ayotte, J.D., Nolan, B.T., Nuckols, J.R., Cantor, K.P., Robinson, G.R., Jr., Baris, Dalsu, Hayes, Laura, Silverman, D.T., and Lubin, Jay, 2006, Modeling the probability of arsenic in ground water in New England as a tool for exposure assessment: Environmental Science and Technology, v. 40, no. 11, p. 3578-3585.

D'Angelo, D., Norton, S.A., Loiselle, M.C., 1996. Historical Uses and Fate of Arsenic in Maine. Water Research Institute Completion Report 1986. University of Maine. Orono, Maine.

Peryea, F.J., 1998. Historical use of lead arsenate insecticides, resulting soil contamination and implications for soil remediation. In: Proc. $16^{\text {th }}$ World Congress of Soil Science. Montpellier, France. Science Reg. No. 274. Symposium 25.

Robinson, G. R., Jr. and Ayotte, J.D., 2006, The influence of geology and land use on arsenic in stream sediments and ground waters in New England, USA: Applied Geochemistry, v. 21, p. 1482-1497. 
Robinson, G.R., Jr. and Kapo, K.E., 2003. Generalized lithology and lithogeochemical character of near-surface bedrock in the New England region. U.S. Geological Survey Open-File Report 03-225 . http://pubs.usgs.gov/of/2003/of03-225/

U.S. Department of Agriculture. 1935-1997. Census of Agriculture. Volume 1, Geographic Area Series. Table 1, County Summary Highlights. National Agriculture Statistics Service, Washington, D.C.

Welch, A.H., Westjohn, D.B., Helsel, D.R., and Wanty, R.B., 2000, Arsenic in ground water of the United States: Occurrence and geochemistry: Ground Water, v. 38, no. 4, p. 589-604. 